\title{
THE IMPLEMENTATION OF TOYOTA PRODUCTION SYSTEM (TPS) IN INDIAN MSMES: A STUDY ON THE MOTIVE, BARRIERS, CHALLENGES, SUCCESS FACTOR AND APPLICATIONS
}

\author{
Waseem Akhtar \\ Department of Mechanical Engineering, School of Engineering and Technology, \\ Sharda University, Gr. Noida \\ Afsar Ansari \\ Department of Mechanical Engineering, \\ JNIT college of Engineering and Technology, Jaipur
}

\begin{abstract}
In spite of the fact that research on the Toyota Production System in Indian industry in swell economies is slowly progressing, its implementation has been emphasized by various researchers and practitioners. Micro, Small and Medium Enterprises are the most important economical unit for the developing country or it is called economic backbone of any country. In comparison with large organization these MSMEs provide more jobs, added value and contribute to GDP of any country. Research on this scope is very limited, particularly when compared to the massive amount of enthusiastic studies contributed to successful implementation of TPS in the developing country. To anchor the narrow body of knowledge on this researched scope, this paper presents the current decreases of implementation of TPS in terms of motive, barriers, challenges, success factor and application. To address these issues, a methodological approach was used in two step. First, a comprehensive reviews of state of the arts literature on the issues was performed followed by an analytic approach using a survey of 120 companies in India basically in Northern part of India to complete the research. On validation of the analysis, the results evident that most of the TPS companies agreed that the reasons of TPS implementation are to increase efficiency, to clean up and organized the workplace, to increase customer satisfaction and increase utilization of space and resources. Non-TPS companies believe that issues related to knowledge and awareness/skills are the main reasons for not understanding the TPS implementation. The TPS companies believes that the barriers are the more about employee-related issues and managerial related issues, which includes, lack of labor resources, lack of knowledge and skill to know-how to implement and employee resistance to change, top management always concern about in investment and middle management have dame issues, there were lack of knowledge in managerial level also. TPS company also face challenges in the form of technical knowledge,
\end{abstract}

training and financial resources during the implementation phase of TPS implementation. In addition, only six applications were found- 5S, Kanban, JIT, employee training and quality control found in Northern part of Indian Industries. These finding represent a critical view of the current decrease of TPS implementation in Indian industry and other spring economies.

Keywords- Toyota production system, Toyota production system tools, success factors, barriers and application

\section{INTRODUCTION}

After the publication of a book "The Machine that Change the World" Womack et al., (1990), Toyota Production System underwent a significant and remarkably evaluation over the years, subsequently being consistently accepted as a highly beneficial practices Bhim and Singh Sangwan, (2014). Over the course of time, a numerous number of researcher have explained the various ranges of tools for Toyota production system (TPS), since it has successfully proved in a large variety of industries with many successful cases recorded in study Pearce et al., (2018).

As increasing number of literature studies have found that TPS has significantly contributed to the success of companies in developing countries (e.g. Japan, UK, US, Germany and Italy). Till now this philosophy has been only applied in developing countries and there is little effort taken to investigate TPS implementation in developing country Nawanir et al., (2013). On other hand, the implementation of TPS in Indian industry is not promising. An evidence show there is little respondents from Indian company has implemented TPS practices. Till now, TPS is a new manufacturing methodology especially for Indian industries. This condition bring out a fundamental question: "what are the barriers for the TPS manufacturing adaptation?" 


\section{International Journal of Engineering Applied Sciences and Technology, 2020 \\ Vol. 4, Issue 12, ISSN No. 2455-2143, Pages 102-111 \\ Published Online April 2020 in IJEAST (http://www.ijeast.com)}

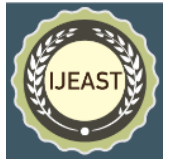

Unfortunately, a majority of micro, small and medium enterprises (MSMEs) have rejected the idea of adopting TPS Bhamu and Singh Sangwan, (2014). Irregardless prior evidence of the benefits of TPS implementation, there are several barriers to it as well including perception, lack of tangible benefits and issues with shop floor employee Melton, (2005). This may largely be due to:

1. The fear of investment cost and the successive benefits of lean Bhamu and Singh Sangwan, (2014)

2. There are scarcity of job security among employees and the risk of losing their jobs if it is non-value added Khaba and Bhar, (2018)

3. There is lack of a supportive organizational culture to overcome the fear of failure, change and uphold the greater responsibility Coetzee et al., (2018)

4. There is lack of governmental or financial support, which is a significant factor of success of TPS implementation Thanki and Thakkar, (2018)

5. Lack of knowledge/skill and training Pearce et al., (2018)

On the behalf of these two companies (TPS and non-TPS companies), a very important questions rise "to what are the motive of TPS implementation adaptation?" The study by Pearce et al., (2018) stresses the importance of knowledge management in the early phase of TPS implementation, which is according to Chay et al. (2015) who published that the lack of technical knowledge among the shop floor employees present the biggest challenges in TPS implementation. Similarly Achanga et al., (2006) also identified the lack of skills among the shop floor employees as an obstacles in TPS implementation, believes that,

1. Adaptation of new environment is dependent on the management considering that TPS is a sustainable philosophy.

2. Technical knowledge and managerial commitment are crucial in ensuring its full implementation

It was also observed that managerial resistance to change, TPS is stunt and TPS is unsustainable Pearce et al., (2018). Shah and Ward (2007) claimed that TPS is multifunctional concept, i.e. it is not scarcely dependent on single principle. This claim was further supported by Achanga et al., (2006), who concluded that the implementation of TPS must not be carried out as separate practices.

To achieve these considerations, this paper is arranged as follows; Section 2 provide literature review; Section 3 addresses the research methodology; Section 4 present the comprehensive results and discussion and in last section conclusion, limitation and recommendation for future research.
To deals with the studies purpose, this take a look at reviewed the literature that investigates the TPS implementation in phrases of motives, barriers, challenges, success factors and applications. This review gives an understanding of the TPS problems through the scenarios performed in developing countries (e.g. the Indian scenarios). In this regards, firstly, this segment affords a background of TPS in context. Following, it present an inclusive issue that drive Indian manufacturing sectors put in force in order to research the reasons and barriers that keep companies form working towards TPS.

\section{BACKGROUND OF TOYOTA PRODUCTION SYSTEM}

Incorporative sector and have various definitions among researchers who have diverse perspective of ideas and different point of views, plans, thought and suggestions Bhamu and Singh Sangwan, (2014)). In generals TPS means manufacturing without waste. Various researchers have pointed TPS is an approach to eliminate waste. On other hand, Shah and Ward (2007) defined TPS as a methods to deliver the extreme value to customers by removing waste through process and human design elements.

TPS can also be defined on the basis of benefits or intension of implementation Melton, (2005). Hallgren et al., (2009) defined TPS as an approach of increasing efficiency of operations, identifying both value and waste, developing knowledge and creating a working culture of continuous improvement to promote sustainability in the process of operation and business management. Other researchers defined TPS based on philosophy of TPS tools. TPS is defined as a people-oriented production system Chay et al., (2015). Besides that, TPS philosophy is not only a multidimensional approach consisting of production with minimum amount of waste (JIT), continuous and unremitting flow (cellular manufacturing), well organized equipment (TPM), well-established quality system (TQM) and well-trained and empowered work force (HRM) that positively impacts operation/competitive performance AlAshraf; Singh and Singh, (2012; 2009). Conjunction, Samuel et al., (2015) identified that many researchers do not agree with any one solid definition for TPS. Their conflict have eventually led to the involvement of TPS definition. Even though it lacks in certain areas, this deficiency has provided an opportunities for researchers to explore for a better TPS ideology.

However, the benefits of lean have been published for over three decades Pearce et al., (2018). Powell et al. (2013) proposed that TPS practices have a positive relationship with the four dimens of operational performance, i.e. quality, lead time performance, flexibility performance and cost performance. Chandrasekaran (2008), figure out that TPS is an effective method in improving operational performance by improvement in its quality, minimization of inventory, delivery, productivity and minimization of waste. Toyota production system is also considered as a powerful technique in improving business performance by improving

\section{LITERATURE REVIEW}




\section{International Journal of Engineering Applied Sciences and Technology, 2020 \\ Vol. 4, Issue 12, ISSN No. 2455-2143, Pages 102-111 \\ Published Online April 2020 in IJEAST (http://www.ijeast.com)}

profitability, sales and customer's satisfaction Rother and Shook, (2003).

\section{MICRO, SMALL AND MEDIUM ENTERPRISES}

Micro, Small and Medium Enterprise (MSMEs) are well organized around the world, both nationally and internationally; as key and significant contributors to economic development, as job creation and health and wellbeing of economies Khaba and Bhar, (2018). In order to facilitate the implementation of LM in MSMEs, a proper understanding of their characteristic will help us in our research.

The Ministry of Industry and Information Technology (MIIT) in India revised the definition of MSMEs which was defined by Small and Medium Enterprise (SMED) Act 2006, the new definition of MSMEs is defined in table 1. It was defined on three categories, (1) on the basic of investment in manufacturing sector (2) on the basic of investment in service sector and (3) on the basic of turnover of that industries.

Table-1. Definition Criteria of MSMEs in India [Times of India]

\begin{tabular}{|l|l|l|l|}
\hline Categories & Manufacturing & Service & Turnover \\
\hline $\begin{array}{l}\text { Micro } \\
\text { Enterprises }\end{array}$ & $\begin{array}{l}\text { Investment up } \\
\text { to Rs.25 lakhs }\end{array}$ & $\begin{array}{l}\text { Investment up } \\
\text { to Rs.10 lakhs }\end{array}$ & $\begin{array}{l}\text { Up to Rs 5 } \\
\text { crore }\end{array}$ \\
\hline $\begin{array}{l}\text { Small } \\
\text { Enterprises }\end{array}$ & $\begin{array}{l}\text { Investment } \\
\text { above Rs.25 } \\
\text { lakh and up to }\end{array}$ & $\begin{array}{l}\text { Investment } \\
\text { above Rs.10 } \\
\text { lakh and up to }\end{array}$ & $\begin{array}{l}\text { Over Rs 5 } \\
\text { crore to Rs 75 } \\
\text { crore }\end{array}$ \\
& Rs.5 crore & Rs.2 crore & \\
\hline $\begin{array}{l}\text { Medium } \\
\text { Enterprises }\end{array}$ & $\begin{array}{l}\text { Investment } \\
\text { above Rs 5 } \\
\text { crore and up to } \\
\text { Rs 10 crore }\end{array}$ & $\begin{array}{l}\text { Investment } \\
\text { above Rs 2 } \\
\text { crore and up } \\
\text { to Rs 5 crore }\end{array}$ & $\begin{array}{l}\text { Over Rs 75 } \\
\text { crore to Rs } \\
150 \text { crore }\end{array}$ \\
& \multicolumn{3}{|l}{} \\
\hline
\end{tabular}

\section{THE IMPLEMENTATION OF TPS IN MSMES}

MSMEs faced tough competition from global markets every day and higher customer demand. The scope with these changing condition many large companies are implementing TPS. TPS offers a holistic strategy to eliminate waste, achieve good quality products and process quality and reduce lead times. While large companies are able to provide the necessary resources and expert who know how to configure and implement the TPS, while MSMEs have lack of these essential resources and financial problem for the organization and they have technological and labor-related challenges.

According to a study by Ramakrishanan et al. (2019) $42 \%$ of MSMEs are those who have tried to implement the TPS methodology in India and only $54 \%$ of those companies have set TPS methodology in application targets for all services. (The samples includes 48 MSMEs in the automotive, manufacturing and service sector in India).

\section{METHODOLOGY}

The study has chosen in year 1990 as the starting year as the implementation of TPS in SMEs was conducted for the first time in this articles: JIT implementation in small manufacturing firms by Golhar, Stamm, and Smith (1990). In the initial search, there were a list of over 1020 research papers associated with the topic of lean, collected from four major management science publishers, namely, Emerald online, Science Direct, Springer Link and Taylor \& Francis. This list was then narrowed by using different keywords that were related only the main research topic.

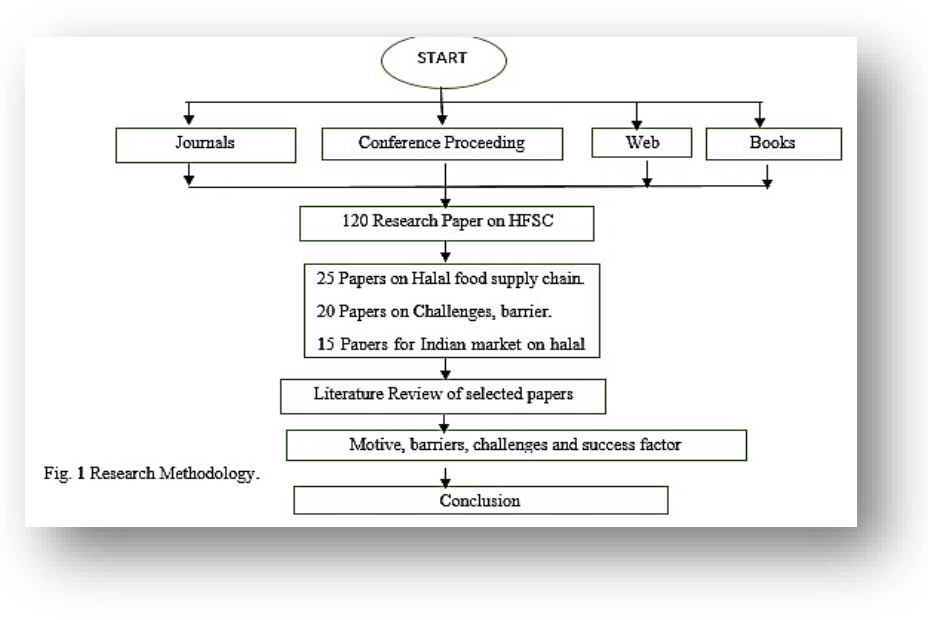

\section{BARRIERS IN TPS IMPLEMENTATION}

A lot of barriers to TPS implementation have been discussed in the literature; the respondents had been limited to include only employees of companies that are practicing TPS. Panwar et al., (2015) embossing that one item under reasons for not implementing TPS was deleted to increase the value of alpha $(\alpha)$ because it is obvious form the customers given that most of the respondent are familiar with Toyota production system. Khaba and Bhar (2018) carried out a study on the cognition of TPS barriers among TPS and nonTPS companies. There was a significant difference in the cognition of four TPS barriers between non-TPS and TPS companies like wise, lack of TPS understanding, resistance to change, financial compellable and lack of TPS trainer and consultant (Khaba and Bhar, 2018). There are some more barriers identified by Abolhassani et al., (2016), lack of technical skills about TPS methods and lack of understanding about its benefits are also restricts in the implementation of TPS for both non-TPS and TPS companies. On the basis of expert's opinion, there is still lack of awareness and TPS implementation in Indian industries due to the fact that TPS is still new for Indian industrialist Shah and Ward, (2003).

\section{MOTIVE FOR ADOPTING TPS IN INDIAN INDUSTRIES}

The growing need of customer and competitive market environment as well as social and economic. The main motive behind TPS implementation is the self desire stemming from the organization's objective Simmons and Walden, (2010). From the extensive review on literature, most TPS practitioners agreed that the reasons for TPS 


\section{International Journal of Engineering Applied Sciences and Technology, 2020 \\ Vol. 4, Issue 12, ISSN No. 2455-2143, Pages 102-111 \\ Published Online April 2020 in IJEAST (http://www.ijeast.com)}

implementation are to improve customer satisfaction Panwar et al., (2015); Pirraglia et al., ( 2009), to minimize the time it takes to deliver products to the markets or customer and to improve quality Williams, (2015); Coetzee et al., (2018). Moreover, there are some contradictions found on some factors. Panwar et al., (2019) who investigated the status of TPS manufacturing in Indian processing industries and highlighted that cost reduction is a significant factor for adopting TPS methodology. Yet Vilkas et al., (2015) found that there is no significant reason to increase utilization of space and supply chain efficiency.

Table-1 Extant literature on the TPS issues- motive, barriers, challenges, success factor and application.

\begin{tabular}{|c|c|c|}
\hline Suggest & Finding/Concept & References \\
\hline Motives & $\begin{array}{l}\text { The significant motives are to } \\
\text { increase customer satisfaction, } \\
\text { waste elimination, decrease } \\
\text { production cost and enhance } \\
\text { productivity, to improve } \\
\text { quality and increase demand } \\
\text { management efficiency. }\end{array}$ & $\begin{array}{l}\text { Panwar et al. } \\
(2015)\end{array}$ \\
\hline Motives & $\begin{array}{l}\text { To improve efficiency and } \\
\text { improve capacity related to } \\
\text { problem-solving and } \\
\text { housekeeping. }\end{array}$ & $\begin{array}{l}\text { Vilkas et al, } \\
(2015)\end{array}$ \\
\hline Motives & $\begin{array}{c}\text { For assist in the achievement } \\
\text { of strategic objective to } \\
\text { enhance efficiency and } \\
\text { maintain marketplace } \\
\text { competitiveness. }\end{array}$ & $\begin{array}{l}\text { Pirraglia et al. } \\
\text { (2009) }\end{array}$ \\
\hline Motives & $\begin{array}{l}\text { Indian industries are working } \\
\text { towards enhancing the quality } \\
\text { of their products, improving } \\
\text { customer satisfaction and } \\
\text { trying to minimize the lead } \\
\text { time. }\end{array}$ & $\begin{array}{l}\text { Achanga et } \\
\text { al. }(2006)\end{array}$ \\
\hline Motives & $\begin{array}{c}\text { Good project quality is ranked } \\
\text { highest while reducing } \\
\text { construction cost is ranked } \\
\text { lowest. } \\
\end{array}$ & $\begin{array}{l}\text { Shah and } \\
\text { Ward (2003) }\end{array}$ \\
\hline Barriers & $\begin{array}{l}\text { Significant reason to not } \\
\text { option for implementing lean } \\
\text { are large batch production is } \\
\text { necessary for capacity } \\
\text { utilization and lack of } \\
\text { education and expertise on } \\
\text { lean. Lack of time and lack of } \\
\text { financial resources are not the } \\
\text { reason for not adopting lean. } \\
\text { The "unfamiliar with lean" } \\
\text { was detected because most } \\
\text { respondents answers that they } \\
\text { were with lean manufacturing. }\end{array}$ & $\begin{array}{l}\text { Panwar et al. } \\
\text { (2015) }\end{array}$ \\
\hline Barriers & $\begin{array}{l}\text { Insufficient training on lean, } \\
\text { insufficient employee } \\
\text { recognition applications on } \\
\text { lean, underneath-usage of } \\
\text { method development } \\
\text { statistical tools and ambiguity } \\
\text { approximately appropriate } \\
\text { lean equipment to be used are } \\
\text { the limitations. Employee }\end{array}$ & $\begin{array}{l}\text { Thanki and } \\
\text { Thakkar } \\
(2014)\end{array}$ \\
\hline
\end{tabular}

\begin{tabular}{|c|c|c|}
\hline & $\begin{array}{l}\text { unwilling to put-off or } \\
\text { manipulate the stated } \\
\text { obstacles. }\end{array}$ & \\
\hline Barriers & $\begin{array}{l}\text { Lack of knowledge about lean } \\
\text { philosophy, unskilled human } \\
\text { resources and insufficient } \\
\text { financial resources are the } \\
\text { barriers. Moreover, half of the } \\
\text { respondent believed that } \\
\text { culture and human attitude } \\
\text { issues, lack of government } \\
\text { support and resistance to } \\
\text { change is the barriers. }\end{array}$ & $\begin{array}{l}\text { Bajjou and } \\
\text { Chafi (2018) }\end{array}$ \\
\hline Barriers & $\begin{array}{l}\text { The knowledge and } \\
\text { management areas indicated } \\
\text { the highest driving power and } \\
\text { lower dependent such as } \\
\text { inadequate management time } \\
\text { as well as deficiencies in } \\
\text { supervisory and senior } \\
\text { management skills. }\end{array}$ & $\begin{array}{l}\text { Bhamu and } \\
\text { Sangwan } \\
(2014)\end{array}$ \\
\hline Barriers & $\begin{array}{l}\text { Employee example: lack of } \\
\text { well-trained and experienced } \\
\text { staff, knowledge about } \\
\text { existing specialist, } \\
\text { management commitment, } \\
\text { coaching, communication, } \\
\text { support, employee } \\
\text { development and job security. } \\
\text { There is greater focus on lean } \\
\text { tools at the expense of the } \\
\text { human side of lean } \\
\text { management. }\end{array}$ & $\begin{array}{l}\text { Coetzee et al. } \\
(2018)\end{array}$ \\
\hline Barriers & $\begin{array}{l}\text { Cultural difference at } \\
\text { workplace are the main for } \\
\text { both lean and non-lean } \\
\text { organization. There are } \\
\text { significant differences in the } \\
\text { perception between lean and } \\
\text { non-lean organization on the } \\
\text { lack of lean understanding, } \\
\text { resistance to change, financial } \\
\text { capability and lack of } \\
\text { consultant and trainers. }\end{array}$ & $\begin{array}{l}\text { Khaba and } \\
\text { Bhar (2018) }\end{array}$ \\
\hline Barriers & $\begin{array}{c}12 \text { vital barriers were } \\
\text { identified. Six variables are } \\
\text { from high rejection rate } \\
\text { (inadequate coaching program, } \\
\text { insufficient regular } \\
\text { maintenance, inferior quality } \\
\text { materials provided by } \\
\text { supplier, lowly examination of } \\
\text { vendors, deteriorating } \\
\text { machine, problematic } \\
\text { supervisor-worker } \\
\text { communication); two were } \\
\text { from the worker absence (un- } \\
\text { maintained worker, leader } \\
\text { relationship, work boredom); } \\
\text { and four were from frequent } \\
\text { breakdown factors } \\
\text { (overworked machines, work } \\
\text { negligence, non-replacement } \\
\text { of impaired machine elements } \\
\text { and disrespect of warning }\end{array}$ & $\begin{array}{l}\text { Kezia and Sai } \\
\text { (2017) }\end{array}$ \\
\hline
\end{tabular}


International Journal of Engineering Applied Sciences and Technology, 2020

Vol. 4, Issue 12, ISSN No. 2455-2143, Pages 102-111

Published Online April 2020 in IJEAST (http://www.ijeast.com)

\begin{tabular}{|c|c|c|}
\hline & $\begin{array}{c}\text { signals given by the } \\
\text { machines). }\end{array}$ & \\
\hline Factors & $\begin{array}{c}\text { In order to successful } \\
\text { implementation of lean } \\
\text { manufacturing concept with in } \\
\text { MSMEs, the recipient } \\
\text { companies should keep strong } \\
\text { leadership and capable of } \\
\text { exhibiting excellent project } \\
\text { management. A good } \\
\text { leadership ultimately promote } \\
\text { effective skills and knowledge } \\
\text { enhancement among its } \\
\text { workforce. }\end{array}$ & $\begin{array}{l}\text { Panwar et al. } \\
\text { (2015) }\end{array}$ \\
\hline Factors & $\begin{array}{l}\text { The production of a strong } \\
\text { hierarchical culture is a basic } \\
\text { stage for the usage of lean } \\
\text { manufacturing. The ability to } \\
\text { operate in diverse environment } \\
\text { is a pre-requisite for managers. } \\
\text { High performing organization } \\
\text { are those with a culture of } \\
\text { practical and proactive } \\
\text { improvement. }\end{array}$ & $\begin{array}{l}\text { Powell et al. } \\
(2013)\end{array}$ \\
\hline Factors & $\begin{array}{l}\text { A company should have wide } \\
\text { long-term direction, objective } \\
\text { and goals for improvement. } \\
\text { Company should need to } \\
\text { know what your end goal and } \\
\text { communicate with everyone in } \\
\text { your team. Aligned with the } \\
\text { company vision, strategy share } \\
\text { your vision throughout. }\end{array}$ & $\begin{array}{l}\text { Bhasin } \\
(2008)\end{array}$ \\
\hline Factors & $\begin{array}{l}\text { Most MSMEs utilize } \\
\text { individuals with low aptitude } \\
\text { levels and they don't } \\
\text { encourage the belief system of } \\
\text { ability improvement. Low } \\
\text { level representative abilities } \\
\text { would not harness the desire } \\
\text { for innovation advancement. }\end{array}$ & $\begin{array}{l}\text { Simmons and } \\
\text { Walden } \\
(2010)\end{array}$ \\
\hline Factors & $\begin{array}{l}\text { Budgetary limits is a critical } \\
\text { factor in the assurance of any } \\
\text { fruitful projects. This is } \\
\text { because of the way that } \\
\text { finance covers the roads } \\
\text { through which other helpful } \\
\text { arrangements like consultancy } \\
\text { and preparing can be made. } \\
\text { Training of people to utilize } \\
\text { the techniques also requires } \\
\text { financial resources. }\end{array}$ & $\begin{array}{l}\text { Abdullah et } \\
\text { al. (2008) }\end{array}$ \\
\hline Factors & $\begin{array}{l}\text { Communication in any } \\
\text { organization is important, but } \\
\text { particularly in a manufacturing } \\
\text { environment where multiple } \\
\text { shift are employed. When } \\
\text { communication does not } \\
\text { occur, products and quality } \\
\text { may suffer and displeasure } \\
\text { between workers may occur. } \\
\text { Lean manufacturing require } \\
\text { clear communication, not only } \\
\text { between shifts but also } \\
\text { between all value streams. } \\
\text { Lean manufacturing must have }\end{array}$ & $\begin{array}{l}\text { Osman et al. } \\
(2019)\end{array}$ \\
\hline
\end{tabular}

\begin{tabular}{|c|c|c|}
\hline & $\begin{array}{l}\text { communication pathway that } \\
\text { are effective and broad. }\end{array}$ & \\
\hline Factors & $\begin{array}{l}\text { Company need to view } \\
\text { training costs as investment, } \\
\text { availability of adequate } \\
\text { resources for an organization } \\
\text { wide training. Without } \\
\text { appropriate training and } \\
\text { instruction, a plant isn't } \\
\text { succeed with the lean } \\
\text { implementation. Managers } \\
\text { also need training and } \\
\text { instruction, the education of } \\
\text { managers is reported to be } \\
\text { more important than educating } \\
\text { employees. }\end{array}$ & $\begin{array}{l}\text { Alkhoraif } \\
\text { (2019) }\end{array}$ \\
\hline Factors & $\begin{array}{l}\text { The system should be clear } \\
\text { with respects the vision and } \\
\text { the bearing of the } \\
\text { organization. There must be } \\
\text { clear definitions of goals, } \\
\text { expectation and deliverability. } \\
\text { Finally, the organization must } \\
\text { carefully define why the lean } \\
\text { philosophy is being } \\
\text { implemented. }\end{array}$ & $\begin{array}{l}\text { Anvari } \\
(2011)\end{array}$ \\
\hline Factors & $\begin{array}{l}\text { Management should always be } \\
\text { concern to improve the } \\
\text { efficiency of the organization. } \\
\text { Management and employees } \\
\text { make his mind in the way to } \\
\text { development or improvement } \\
\text { and always try to identify the } \\
\text { area of improvement. A good } \\
\text { manager and employees never } \\
\text { repeat the old procedure in the } \\
\text { organization }\end{array}$ & $\begin{array}{l}\text { Putnik et al. } \\
(2012)\end{array}$ \\
\hline Challenges & $\begin{array}{l}\text { The big challenges are to } \\
\text { assist small batch production, } \\
\text { lack of training and to arrange } \\
\text { TPS implementation experts. }\end{array}$ & $\begin{array}{l}\text { Panwar et al. } \\
(2015)\end{array}$ \\
\hline Challenges & $\begin{array}{c}\text { The technical challenges are } \\
\text { lack of know-how and } \\
\text { management support on } \\
\text { adopting sustainability } \\
\text { practices. }\end{array}$ & $\begin{array}{l}\text { Rahim et al. } \\
\text { (2019) }\end{array}$ \\
\hline Challenges & $\begin{array}{l}\text { The big challenges of TPS and } \\
\text { sustainability integration are } \\
\text { failure to properly identify and } \\
\text { address the implementation on } \\
\text { long term sustainability. }\end{array}$ & $\begin{array}{l}\text { Vilkas et al. } \\
(2015)\end{array}$ \\
\hline Challenges & $\begin{array}{l}\text { There are ten challenges } \\
\text { identified were lack of } \\
\text { material requirements } \\
\text { planning system, poor core } \\
\text { information, a lack of core } \\
\text { material, poor spare parts } \\
\text { information and insufficient } \\
\text { quality management practices, } \\
\text { huge inventory and lack of } \\
\text { supply chain management. }\end{array}$ & $\begin{array}{l}\text { Pearce et al. } \\
(2018)\end{array}$ \\
\hline Challenges & $\begin{array}{l}\text { Emergence the main issues in } \\
\text { managerial staff and their } \\
\text { resistance to change basically } \\
\text { middle management. }\end{array}$ & $\begin{array}{l}\text { Reid and } \\
\text { Sanders } \\
(2015)\end{array}$ \\
\hline
\end{tabular}




\begin{tabular}{|c|c|c|}
\hline Challenges & $\begin{array}{l}\text { The formation of TPS team } \\
\text { need the involvement of the } \\
\text { company employees as well as } \\
\text { academics or consultants that } \\
\text { represent the expert on TPS. }\end{array}$ & $\begin{array}{l}\text { Wahab and } \\
\text { Sulaiman } \\
(2017)\end{array}$ \\
\hline Challenges & $\begin{array}{l}\text { There are four challenges } \\
\text { identified were to define what } \\
\text { is waste, what is value, what is } \\
\text { constraints and how to support } \\
\text { design process in a TPS } \\
\text { oriented way. }\end{array}$ & $\begin{array}{l}\text { York and } \\
\text { Chen (2018) }\end{array}$ \\
\hline Applications & $\begin{array}{l}\text { The highest TPS tools utilized } \\
\text { were 5S, visual control, work } \\
\text { standardization, Kanban, } \\
\text { Poka-Yoke and value stream } \\
\text { mapping were used in Indian } \\
\text { industries }\end{array}$ & $\begin{array}{l}\text { Panwar et al. } \\
\text { (2015) }\end{array}$ \\
\hline Applications & $\begin{array}{l}\text { The most successive used of } \\
\text { TPS practices are: employee } \\
\text { training on TPS principle and } \\
\text { practices, integration of } \\
\text { quality control into work } \\
\text { process, work standardization } \\
\text { and 5S. } \\
\text { a }\end{array}$ & $\begin{array}{l}\text { Vilkas et al. } \\
(2015)\end{array}$ \\
\hline Applications & $\begin{array}{c}\text { Industries } 4.0 \text { and TPS can } \\
\text { coincide and complement each } \\
\text { other, TPS tools used to assist } \\
\text { industry } 4.0 \text { and JIT, Kanban, } \\
\text { VSM, TPM, SMED, poka- } \\
\text { yoke and 5S. }\end{array}$ & $\begin{array}{l}\text { Singh and } \\
\text { Sharma } \\
(2010)\end{array}$ \\
\hline Applications & $\begin{array}{c}\text { Standard operation, } \\
\text { continuous flow, Kanban, } \\
\text { teamwork, employee training, } \\
\text { design of continuous flow and } \\
\text { support partnership were } \\
\text { suggested for optimization } \\
\text { cycle time and lead time. }\end{array}$ & $\begin{array}{l}\text { Coetzee et al. } \\
\text { (2018) }\end{array}$ \\
\hline
\end{tabular}

\section{CHALLENGES WHILE IMPLEMENTING TPS}

This study reviewed the prevailing challenges of TPS implementation, so that the key observation and perception could be summarized to guide Indian industries towards TPS transformation. Rawabdeh (2005) proposed a new TPS framework which was established form the drivers and barriers to TPS implementation. Limitations need to be identified earlier so that industries can take consciousness of their ability, be better equipped for the implementation of TPS and be unfaltering consistent process-wise Singh and Singh, (2009). Moreover, TPS deployment requires changes in structure, system, process and employee behavior in accordance to the transformation plan Pattanaik and Sharma, (2009).

\section{SUCCESS FACTORS OF TPS IMPLEMENTATION}

Success factors are those few thing that the majority go well to make sure success for a manager or an organization and thus, they represent those managerial or enterprises areas that must be give special and continual attention to bring high performance by Boynton and Zmud, (1984).
Alternatively, it can be said that the SF are the select few overarching requirements that must be present for an organization to be able to attain its vision and to be guided toward its vision. The success depends on customers program, stakeholders, people and process. it was found that the most important success factors to have successfully implemented TPS manufacturing are employees involvement and culture change Petroni, (2002). Top management commitment is one of the most important factor for implementation of TPS manufacturing Floyd and McManus, (2002). Effective and transparent communication one of the most important drives of TPS implementation in manufacturing Panwar and Rathore, (2015). Pearce et al. (2018) conducted case studies on two first industries which were first time implementation of TPS manufacturing. The authors highlighted that the key issues were handling staff and their resistance to change. Melton (2005), pointed that the financial capabilities is also a crucial factor of TPS implementation in Indian industries.

\section{APPLICATIONS OF TPS IMPLEMENTATION}

There are almost 100 tools for TPS practices and with time, there are going to be more and extensive collections of TPS practices as suggested by various researchers Antony et al., (2016). The selection of TPS practices should be made wisely to guarantee a successful implementation. Chay et al. (2015) identified failure to engage with shop floor employee, poor supervision skills and lack of knowledge Urban and Naidoo, (2012) as the obstacles in lean transformation. According to Anvari et al. (2011), the selection of TPS practices should be made based on the nature of the process or works. It is important that a manufacturing has enough knowledge on lean practices, so that they understand the working of TPS implementation.

Table-2. The summery of published studies on the TPS issues.

\begin{tabular}{|c|c|c|}
\hline Issues & $\begin{array}{l}\text { Motive/Applicatio } \\
\text { ns }\end{array}$ & $\begin{array}{l}\text { References/Sourc } \\
\text { es }\end{array}$ \\
\hline \multirow[t]{13}{*}{$\begin{array}{l}\text { 1. Motive of } \\
\text { adopting TPS } \\
\text { practices }\end{array}$} & $\begin{array}{l}\text { To } \\
\text { customers } \\
\text { satisfaction }\end{array}$ & Panwar et al. (2015) \\
\hline & $\begin{array}{ll}\begin{array}{l}\text { Satisfaction } \\
\text { customers }\end{array} & \text { of } \\
\end{array}$ & Vilkas et al. (2015) \\
\hline & $\begin{array}{lr}\text { To } & \text { improve } \\
\text { customers satisfaction }\end{array}$ & Pirraglia et al. (2009) \\
\hline & To eliminate waste & Vilkas et al. (2015) \\
\hline & $\begin{array}{l}\text { Eliminations of } \\
\text { wastes }\end{array}$ & Panwar et al. (2015) \\
\hline & $\begin{array}{l}\text { To minimize the } \\
\text { production cost }\end{array}$ & Panwar et al. (2015) \\
\hline & Profit & Vilkas et al. (2015) \\
\hline & $\begin{array}{l}\text { Minimizing the } \\
\text { planning and design } \\
\text { cost }\end{array}$ & $\begin{array}{l}\text { Bajjou and Chafi } \\
(2018)\end{array}$ \\
\hline & Cost reduction & Pirraglia et al. (2009) \\
\hline & $\begin{array}{l}\text { Lower costs and } \\
\text { faster turnover }\end{array}$ & $\begin{array}{l}\text { Achanga et al. } \\
(2006)\end{array}$ \\
\hline & To improve quality & Panwar et al. (2015) \\
\hline & Quality products & Vilkas et al. (2015) \\
\hline & $\begin{array}{l}\text { Improvement } \\
\text { service quality }\end{array}$ & Pirraglia et al. (2009) \\
\hline
\end{tabular}


International Journal of Engineering Applied Sciences and Technology, 2020

Vol. 4, Issue 12, ISSN No. 2455-2143, Pages 102-111

Published Online April 2020 in IJEAST (http://www.ijeast.com)

\begin{tabular}{|c|c|c|}
\hline & Improving the quality & Pirraglia et al. (2009) \\
\hline & $\begin{array}{l}\text { New product } \\
\text { development }\end{array}$ & Vilkas et al. (2015) \\
\hline & To solve problem & Vilkas et al. (2015) \\
\hline & $\begin{array}{l}\text { Identification and } \\
\text { solving the problems }\end{array}$ & Vilkas et al. (2015) \\
\hline & $\begin{array}{ll}\begin{array}{l}\text { To } \\
\text { efficiency }\end{array} & \text { increase } \\
\end{array}$ & Coetzee et al. (2018) \\
\hline & $\begin{array}{ll}\text { To } & \text { improve } \\
\text { efficiency }\end{array}$ & Panwar et al. (2015) \\
\hline & $\begin{array}{l}\text { To increase supply } \\
\text { chain efficiency }\end{array}$ & Panwar et al. (2015) \\
\hline & $\begin{array}{l}\text { Increase management } \\
\text { efficiency }\end{array}$ & $\begin{array}{l}\text { Singh and Singh } \\
(2009)\end{array}$ \\
\hline \multirow{20}{*}{$\begin{array}{l}\text { 2. Barriers in } \\
\text { TPS } \\
\text { implementati } \\
\text { on }\end{array}$} & $\begin{array}{l}\text { Middle and Top } \\
\text { management } \\
\text { resistance to change }\end{array}$ & $\begin{array}{lcr}\text { Pirraglia } & \text { et al. } \\
(2009), & \text { Upadhye } \\
(2010), & \text { Soon }(2016)\end{array}$ \\
\hline & $\begin{array}{l}\text { Deficiency in senior } \\
\text { management interest } \\
\text { and support }\end{array}$ & Panwar et al. (2015) \\
\hline & $\begin{array}{l}\text { Lack of management } \\
\text { commitment }\end{array}$ & Panwar et al. (2015) \\
\hline & $\begin{array}{l}\text { Management } \\
\text { resistance to change }\end{array}$ & $\begin{array}{l}\text { Shah and Ward } \\
(2007)\end{array}$ \\
\hline & $\begin{array}{l}\text { Lack of commitment } \\
\text { from top management }\end{array}$ & Kezia and Sai (2017) \\
\hline & $\begin{array}{l}\text { Lack of senior } \\
\text { management } \\
\text { commitment }\end{array}$ & $\begin{array}{l}\text { Shah and Ward } \\
(2003)\end{array}$ \\
\hline & $\begin{array}{l}\text { Employee resistance } \\
\text { to change }\end{array}$ & $\begin{array}{l}\text { Bajjou and Chafi } \\
(2018) \text {, Khaba and } \\
\text { Bhar } \quad(2018) \text {, } \\
\text { Pandiaraj (2008) }\end{array}$ \\
\hline & Employee resistance & Pirraglia et al. (2009) \\
\hline & $\begin{array}{l}\text { Unwillingness } \\
\text { learn and see }\end{array}$ & Vilkas et al. (2015) \\
\hline & Employee attitude & $\begin{array}{ll}\text { Pattanaik } & \text { and } \\
\text { Sharma (2009) } & \end{array}$ \\
\hline & $\begin{array}{ll}\begin{array}{l}\text { Lack } \\
\text { empowerment } \\
\text { employee }\end{array} & \begin{array}{l}\text { of } \\
\text { of }\end{array} \\
\end{array}$ & Rajeev (2008) \\
\hline & Attitude of workman & Melton (2005) \\
\hline & $\begin{array}{l}\text { Lack of expertise on } \\
\text { TPS }\end{array}$ & Panwar et al. (2015) \\
\hline & $\begin{array}{lr}\text { Lack } & \text { of } \\
\text { understanding } & \text { about } \\
\text { TPS } & \\
\end{array}$ & Vilkas et al. (2015) \\
\hline & Lack of methodology & Upadhye (2010) \\
\hline & $\begin{array}{l}\text { Lack of } \\
\text { consultant } \\
\text { trainers }\end{array}$ & $\begin{array}{l}\text { Singh and Singh } \\
(2009)\end{array}$ \\
\hline & $\begin{array}{l}\text { Inadequate } \\
\text { knowledge and TPS } \\
\text { expertise }\end{array}$ & $\begin{array}{l}\text { Shah and Ward } \\
(2003)\end{array}$ \\
\hline & $\begin{array}{l}\text { TPS is difficult to } \\
\text { implement }\end{array}$ & Coetzee et al. (2018) \\
\hline & $\begin{array}{l}\text { TPS is difficult is } \\
\text { implement }\end{array}$ & Vilkas et al. (2015) \\
\hline & $\begin{array}{l}\text { Not easy to } \\
\text { implement }\end{array}$ & Panwar et al. (2015) \\
\hline $\begin{array}{l}\text { 3. Challenges } \\
\text { while } \\
\text { implementing } \\
\text { TPS }\end{array}$ & $\begin{array}{l}\text { Lack of employee } \\
\text { commitment }\end{array}$ & $\begin{array}{l}\text { Bajjou and Chafi } \\
(2018)\end{array}$ \\
\hline
\end{tabular}

\begin{tabular}{|c|c|c|}
\hline & Attitude of workman & $\begin{array}{l}\text { Sahoo and Yadav } \\
(2018)\end{array}$ \\
\hline & $\begin{array}{l}\text { Change in employee } \\
\text { behavior }\end{array}$ & Pearce et al. (2018) \\
\hline & $\begin{array}{l}\text { Worker resistance to } \\
\text { change }\end{array}$ & $\begin{array}{l}\begin{array}{l}\text { Achanga } \\
(2006)\end{array} \\
(20 \text { al. }\end{array}$ \\
\hline & Employee relations & $\begin{array}{l}\text { Pirraglia and Saloni } \\
\text { (2009) }\end{array}$ \\
\hline & $\begin{array}{l}\text { Lack of senior } \\
\text { management } \\
\text { interest and support }\end{array}$ & Antony et al. (2012) \\
\hline & $\begin{array}{l}\text { Lack of management } \\
\text { commitment }\end{array}$ & $\begin{array}{l}\text { Thanki and Thakkar } \\
\text { (2014) }\end{array}$ \\
\hline & $\begin{array}{l}\text { Lack of } \text { TPS } \\
\text { awareness program } \\
\text { for employee }\end{array}$ & $\begin{array}{l}\text { Sahoo and Yadav } \\
(2018)\end{array}$ \\
\hline & $\begin{array}{ll}\text { Lack of senior } \\
\text { management } \\
\text { commitment }\end{array}$ & Pearce at al. (2018) \\
\hline & $\begin{array}{l}\text { Lack of management } \\
\text { understanding }\end{array}$ & $\begin{array}{lll}\begin{array}{l}\text { Achanga } \\
(2006)\end{array} & \text { et } & \text { al. } \\
\end{array}$ \\
\hline & $\begin{array}{l}\text { Poor communication } \\
\text { and leadership }\end{array}$ & $\begin{array}{l}\text { Bajjou and Chafi } \\
(2018)\end{array}$ \\
\hline & $\begin{array}{l}\text { Lack of technical } \\
\text { knowledge }\end{array}$ & $\begin{array}{l}\text { Osman and Rahim } \\
(2019)\end{array}$ \\
\hline & $\begin{array}{l}\text { Uncertainty regarding } \\
\text { the appropriate tools } \\
\text { and technique }\end{array}$ & Panwar et al. (2015) \\
\hline & $\begin{array}{l}\text { Inadequate } \\
\text { knowledge and TPS } \\
\text { expertise }\end{array}$ & $\begin{array}{l}\text { Thanki and Thakkar } \\
\text { (2014) }\end{array}$ \\
\hline & $\begin{array}{lr}\text { Lack of } & \text { skills, } \\
\text { knowledge } & \text { and } \\
\text { expertise } & \end{array}$ & $\begin{array}{l}\text { Sahoo and Yadav } \\
(2018)\end{array}$ \\
\hline & $\begin{array}{l}\text { Lack of } \\
\text { understanding of TPS }\end{array}$ & Pirraglia et al. (2009) \\
\hline & Inadequate training & Panwar et al. (2015) \\
\hline & Lack of TPS training & $\begin{array}{l}\text { Shah and Ward } \\
(2007)\end{array}$ \\
\hline & Poor training & 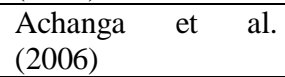 \\
\hline & $\begin{array}{l}\text { Organizational } \\
\text { learning }\end{array}$ & Kezia and Sai (2017) \\
\hline & $\begin{array}{ll}\text { Not easy } & \text { to } \\
\text { implement }\end{array}$ & Coetzee et al. (2018) \\
\hline & Supplier unreliability & Pirraglia et al. (2015) \\
\hline & $\begin{array}{l}\text { Improper information } \\
\text { exchange }\end{array}$ & Melton (2005) \\
\hline & $\begin{array}{l}\text { Difficulty of applying } \\
\text { TPS technique }\end{array}$ & Simmons (2010) \\
\hline & $\begin{array}{l}\text { High } \\
\text { variability }\end{array}$ & Coetzee et al. (2018) \\
\hline $\begin{array}{l}\text { 4. Application } \\
\text { of TPS } \\
\text { implementati } \\
\text { on }\end{array}$ & $\begin{array}{l}\text { 5S- Five (5S) } \\
\text { Method }\end{array}$ & $\begin{array}{l}\text { Bhamu and Sangwan } \\
(2014), \quad \text { Melton } \\
(20005) \text {, Pirraglia et } \\
\text { al. (2009), Shah and } \\
\text { Ward (2007) }\end{array}$ \\
\hline & $\begin{array}{l}\text { 5S (Seiri, Seiton, } \\
\text { Seiso, Seiketsu and } \\
\text { Shitsuke) }\end{array}$ & Pirraglia et al. (2009) \\
\hline & $\begin{array}{l}\text { Workplace } \\
\text { organization }\end{array}$ & $\begin{array}{l}\text { Thanki and Thakkar } \\
(2018)\end{array}$ \\
\hline & $\begin{array}{l}\text { Workplace } \\
\text { management }\end{array}$ & Vilkas et al. (2015) \\
\hline
\end{tabular}


International Journal of Engineering Applied Sciences and Technology, 2020

Vol. 4, Issue 12, ISSN No. 2455-2143, Pages 102-111

Published Online April 2020 in IJEAST (http://www.ijeast.com)

\begin{tabular}{|c|c|c|}
\hline & Process mapping & $\begin{array}{l}\text { Pirraglia et al. } \\
(2015), \text { Vilkas et al. } \\
(2015), \quad \text { Melton } \\
(2005)\end{array}$ \\
\hline & Process flow mapping & $\begin{array}{l}\text { Achanga et al. } \\
(2006)\end{array}$. \\
\hline & $\begin{array}{l}\text { Waste identification } \\
\text { and elimination }\end{array}$ & Pirraglia et al. (2009) \\
\hline & Waste reduction & $\begin{array}{l}\text { Thanki and Thakkar } \\
\text { (2018) }\end{array}$ \\
\hline & $\begin{array}{l}\text { Waste, inventory and } \\
\text { variability reduction }\end{array}$ & $\begin{array}{l}\text { Singh and Sharma } \\
(2010)\end{array}$ \\
\hline & $\begin{array}{l}\text { Kaizen/Continuous } \\
\text { improvement }\end{array}$ & $\begin{array}{l}\text { Sahoo and Yadav } \\
\text { (2018), Bajjou and } \\
\text { Chafi (2018), Vilkas } \\
\text { et al. (2015) }\end{array}$ \\
\hline & $\begin{array}{l}\text { Continuous } \\
\text { improvement } \\
\text { program }\end{array}$ & $\begin{array}{l}\text { Bhamu and Sangwan } \\
\text { (2014) }\end{array}$ \\
\hline & $\begin{array}{l}\text { Continuous } \\
\text { improvement }\end{array}$ & 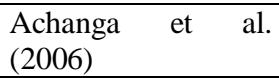 \\
\hline & Kaizen circles & $\begin{array}{l}\text { Wahab and } \\
\text { Sulaiman (2017) }\end{array}$ \\
\hline & $\begin{array}{l}\text { Workforce } \\
\text { involvement }\end{array}$ & $\begin{array}{l}\text { York and Chin } \\
(2018)\end{array}$ \\
\hline & Just in time (JIT) & $\begin{array}{l}\text { Bhamu and Sangwan } \\
\text { (2014), Jasti and } \\
\text { Kodali (2014), } \\
\text { Thanki and Thakkar } \\
(2014)\end{array}$ \\
\hline & $\begin{array}{ll}\text { JIT delivery } & \text { by } \\
\text { supplier } & \end{array}$ & $\begin{array}{l}\text { Shah and Ward } \\
(2007)\end{array}$ \\
\hline & $\begin{array}{l}\text { JIT links with } \\
\text { customers }\end{array}$ & Yang et al. (2011) \\
\hline & $\begin{array}{l}\text { JIT manufacturing } \\
\text { and delivery }\end{array}$ & $\begin{array}{lll}\begin{array}{l}\text { Shah and } \\
(2003)\end{array} & \text { Ward } \\
\end{array}$ \\
\hline & Just in time flow & Averill (2017) \\
\hline & Continuous flow & $\begin{array}{l}\text { Osman and Rahim } \\
(2019)\end{array}$ \\
\hline $\begin{array}{l}\text { 5. Success } \\
\text { Factors }\end{array}$ & $\begin{array}{l}\text { Strong leadership } \\
\text { and administration }\end{array}$ & Kotter (2007) \\
\hline & Company culture & $\begin{array}{l}\text { Sharma and Shah } \\
(2016)\end{array}$ \\
\hline & $\begin{array}{l}\text { Establishment of } \\
\text { goals and objective }\end{array}$ & $\begin{array}{l}\text { Panwar et al. (2015), } \\
\text { Pirraglia et al. (2009) }\end{array}$ \\
\hline & Skills and expertise & $\begin{array}{l}\text { Bhasin (2008), } \\
\text { Antony et al. (2002) }\end{array}$ \\
\hline & Financial capacity & Hamid et al. (2019) \\
\hline & $\begin{array}{ll}\text { Effective } & \text { and } \\
\text { transparent } & \\
\text { communication } & \end{array}$ & Osman et al. (2019) \\
\hline & $\begin{array}{l}\text { Education } \\
\text { training }\end{array}$ & Powell et al. (2013) \\
\hline & Plan and strategy & Anvari et al. (2011) \\
\hline & $\begin{array}{ll}\text { Thinking } & \text { and } \\
\text { development }\end{array}$ & Pandiaraj (2008) \\
\hline
\end{tabular}

\section{CONCLUSION}

The research is among the very limited number of studies, which have investigated the current scenario of implementing the TPS manufacturing in the Indian MSMEs in terms of motives, barriers, challenges, success factors and applications. The following is a summary of the conclusions, which can contribute to support the distressed of knowledge on the under-researched scope.

- This study found that generally the motives for adopting TPS practices are to increase efficiency, utilization of space and maintained organized workplace. In this study, found that most of the TPS tools used in Indian industries are 5S tools which is a basis TPS practices used to increase utilization of space and resources by cleaning up and organizing the workplace. The finding show that the companies believe in the benefits of TPS practices and are willing to change for the sustainability of business.

- Demonstration form the study suggested that implementation of TPS in Indian industries is not an easy task, as it is heavy burden by knowledge and resource related barriers. The most obvious finding to emerge from this study is that both TPS and non-TPS companies believed that the knowledge is the prominent issue. There are lack of implementation knowledge and deficiency of expertise on TPS approach.

- This study also identified the barriers which comparable for both TPS and non-TPS companies, our finding show that the companies do not implement TPS because they are not be able to understand the profit gained from practices of TPS. During our study most of the company believe that employee resistance to change was a big problem for that company.

- During this study identified that the strong leader and management play a vital role in implementing the TPS methodology in Indian industries. The contribution of effective and transparent communication is very high which an important factor of TPS implementation was also.

Despite its exploratory nature, this study offers some insight into TPS implementation consciousness while identifying knowledge areas of strength and deficiencies. The results of this study will help government and private industries in India to make some more mature and careful decision regarding the TPS issues and success factors. More information on TPS implementation from Indian industries would help us to established TPS implementation framework towards the successful implementation of TPS in Indian industries.

This study, have some limitations, which suggest some directions for future research. The study was limited number of industries/companies in Indian context. Only MSMEs are considered in this study including, automobile, manufacturing, services, aviation and food/beverage industries. So for future study, the limitation of industries can be increase for the better result.

\section{REFERENCES}

[1] Abdulmalek, F. A., \& Rajgopal, J. (2007). Analyzing the benefits of lean manufacturing and value stream mapping via simulation: A process 


\section{International Journal of Engineering Applied Sciences and Technology, 2020 \\ Vol. 4, Issue 12, ISSN No. 2455-2143, Pages 102-111 \\ Published Online April 2020 in IJEAST (http://www.ijeast.com)}

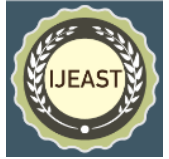

sector case study. International Journal of production economics, 107(1), 223-236.

[2] Abolhassani, A., Layfield, K., \& Gopalakrishnan, B. (2016). Lean and US manufacturing industry: popularity of practices and implementation barriers. International Journal of productivity and performance Management.

[3] Anvari, A., Ismail, Y., \& Hojjati, S. M. H. (2011). A study on total quality management and lean manufacturing: through lean thinking approach. World applied sciences journal, 12(9), 1585-1596.

[4] Bajjou, M. S., \& Chafi, A. (2018). Lean construction implementation in the Moroccan construction industry. Journal of Engineering, Design and Technology.

[5] Bhamu, J., \& Sangwan, K. S. (2014). Lean manufacturing: literature review and research issues. International Journal of Operations \& Production Management.

[6] Bhasin, S. (2008). Lean and performance measurement. Journal of Manufacturing Technology Management.

[7] Boynton, A. C., \& Zmud, R. W. (1984). An assessment of critical success factors. Sloan management review, 25(4), 17-27.

[8] Chandrasekaran, M., Kannan, S., \& Pandiaraj, P. (2008). Quality improvement in automobile assembly production line by using Kaizen. Manufacturing Technology Today, 7(3), 33-38.

[9] Chay, T., Xu, Y., Tiwari, A., \& Chay, F. (2015). Towards lean transformation: the analysis of lean implementation frameworks. Journal of Manufacturing Technology Management.

[10] Clegg, B., MacBryde, J., Dey, P., \& Powell, D. (2013). ERP systems in lean production: new insights from a review of lean and ERP literature. International Journal of Operations \& Production Management.

[11] Coetzee, R., Van Dyk, L., \& Van der Merwe, K. R. (2018). Towards addressing respect for people during lean implementation. International Journal of Lean Six Sigma.

[12] Coetzee, R., Van Dyk, L., \& Van der Merwe, K. R. (2018). Towards addressing respect for people during lean implementation. International Journal of Lean Six Sigma.

[13] Floyd, D., \& McManus, J. (2005). The role of SMEs in improving the competitive position of the European Union. European Business Review.

[14] Golhar, D. Y., Stamm, C. L., \& Smith, W. P. (1990). JIT implementation in small manufacturing firms. Production and Inventory Management Journal, 31(2), 44.

[15] Hallgren, M., \& Olhager, J. (2009). Lean and agile manufacturing: external and internal drivers and performance outcomes. International Journal of Operations \& Production Management.
[16] Hu, Q., Mason, R., Williams, S. J., \& Found, P. (2015). Lean implementation within SMEs: a literature review. Journal of Manufacturing Technology Management.

[17] Kezia, P., Kumar, K. S., \& Sai, B. K. (2017). LEAN MANUFACTURI BEVERAGE. International Journal of Civil Engineering, 8(5).

[18] Khaba, S., \& Bhar, C. (2018). Lean awareness and potential for lean implementation in the Indian coal mining industry. International Journal of Quality \& Reliability Management.

[19] Melton, T. (2005). The benefits of lean manufacturing: what lean thinking has to offer the process industries? Chemical engineering research and design, 83(6), 662-673.

[20] Nawanir, G., Teong, L. K., \& Othman, S. N. (2013). Impact of lean practices on operations performance and business performance: some evidence from Indonesian manufacturing companies. Journal of Manufacturing Technology Management, 24(7), 1019-1050.

[21] Osman, A. A., Othman, A. A., \& Rahim, M. K. I. A. (2019). A REVIEW OF LEAN APPLICATION IN MANUFACTURING ENVIRONMENT: DEFINITIONS AND TERMINOLOGIES. Journal of Technology and Operations Management, 14(2), 28-45.

[22] Panwar, A., Jain, R., \& Rathore, A. P. S. (2015). Lean implementation in Indian process industriessome empirical evidence. Journal of Manufacturing Technology Management.

[23] Pattanaik, L. N., \& Sharma, B. P. (2009). Implementing lean manufacturing with cellular layout: a case study. The International Journal of Advanced Manufacturing Technology, 42(7-8), 772-779.

[24] Pearce, D., Dora, M., Wesana, J., \& Gellynck, X. (2018). Determining factors driving sustainable performance through the application of lean management practices in horticultural primary production. Journal of Cleaner Production, 203, 400-417.

[25] Petroni, A. (2002). Critical factors of MRP implementation in small and medium-sized firms. International Journal of Operations \& Production Management.

[26] Pirraglia, A., Saloni, D., \& Van Dyk, H. (2009). Status of lean manufacturing implementation on secondary wood industries including residential, cabinet, millwork, and panel markets. Bio Resources, 4(4), 1341-1358.

[27] Putnik, G. D., Alves, A. C., Dinis-Carvalho, J., \& Sousa, R. M. (2012). Lean production as promoter of thinkers to achieve companies' agility. The Learning Organization.

[28] Rahani, A. R., \& Al-Ashraf, M. (2012). Production flow analysis through value stream mapping: a lean manufacturing process case study. Procedia Engineering, 41, 1727-1734. 


\section{International Journal of Engineering Applied Sciences and Technology, 2020 \\ Vol. 4, Issue 12, ISSN No. 2455-2143, Pages 102-111 \\ Published Online April 2020 in IJEAST (http://www.ijeast.com)}

[29] Rajeev, N. (2008). Inventory management in small and medium enterprises. Management Research News.

[30] Ramakrishnan, V., Jayaprakash, J., Elanchezhian, C., \& Ramnath, B. V. (2019). Implementation of Lean Manufacturing in Indian SMEs-A case study. Materials Today: Proceedings, 16, 12441250.

[31] Rawabdeh, I. A. (2005). A model for the assessment of waste in job shop environments. International Journal of Operations \& Production Management.

[32] Reid, R. D., \& Sanders, N. R. (2015). Operations management: an integrated approach. John Wiley \& Sons.

[33] Rother, M., \& Shook, J. (2003). Learning to see: value stream mapping to add value and eliminate muda. Lean Enterprise Institute.

[34] Saad, S., Perera, T., Achanga, P., Shehab, E., Roy, R., \& Nelder, G. (2006). Critical success factors for lean implementation within SMEs. Journal of manufacturing technology management.

[35] Sahoo, S., \& Yadav, S. (2018). Lean implementation in small-and medium-sized enterprises. Benchmarking: An International Journal.

[36] Samuel, D., Found, P., \& Williams, S. J. (2015). How did the publication of the book The Machine That Changed The World change management thinking? Exploring 25 years of lean literature. International Journal of Operations \& Production Management.

[37] Shah, R., \& Ward, P. T. (2003). Lean manufacturing: context, practice bundles, and performance. Journal of operations management, 21(2), 129-149.

[38] Shah, R., \& Ward, P. T. (2007). Defining and developing measures of lean production. Journal of operations management, 25(4), 785-805.

[39] Sharma, S., \& Shah, B. (2016). Towards lean warehouse: transformation and assessment using RTD and ANP. International Journal of Productivity and Performance Management.

[40] Simmons, L., Holt, R., Dennis, G., \& Walden, C. (2010, December). Lean implementation in a low volume manufacturing environment: A case study. In Proceedings of the 2010 Industrial Engineering
Research Conference. USA: Mississippi State University.

[41] Singh, B., Garg, S. K., \& Sharma, S. K. (2010). Scope for lean implementation: a survey of 127 Indian industries. International Journal of Rapid Manufacturing, 1(3), 323-333.

[42] Singh, J., \& Singh, H. (2009). Kaizen philosophy: a review of literature. IUP Journal of Operations Management, 8(2), 51.

[43] Soon, J. M., Manning, L., \& Wallace, C. A. (2016). Foodborne diseases: case Studies of outbreaks in the agri-food industries. CRC Press.

[44] Thanki, S., \& Thakkar, J. (2018). A quantitative framework for lean and green assessment of supply chain performance. International Journal of Productivity and Performance Management.

[45] Upadhye, N., Deshmukh, S. G., \& Garg, S. (2010). Lean manufacturing system for medium size manufacturing enterprises: an Indian case. International Journal of Management Science and Engineering Management, 5(5), 362-375.

[46] Urban, B., \& Naidoo, R. (2012). Business sustainability: empirical evidence on operational skills in SMEs in South Africa. Journal of Small Business and Enterprise Development.

[47] Vilkas, M., Koreckaja, I., Katiliūte, E., \& Bagdonienè, D. (2015). Adoption of Lean production: preliminary evidence from Lithuania. Procedia-Social and Behavioral Sciences, 213, 884-889.

[48] Wahab, A. N. A., Mukhtar, M., \& Sulaiman, R. (2017). Lean Production System Definition from the Perspective of Malaysian Industry. AsiaPacific Journal of Information Technology and Multimedia, 6(1).

[49] Womack, J. P., Roos, D., \& Jones, D. T. (1990). The machine that changed the world: Massachusetts Institute of Technology. Rawson Associates, New York, NY

[50] Yadav, V., Jain, R., Mittal, M. L., Panwar, A., \& Lyons, A. (2019). The impact of lean practices on the operational performance of SMEs in India. Industrial Management \& Data Systems.

[51] York, S., Wainright, C., \& Chen, D. C. (2018). Healthcare Supply Chain Management: An Instructive Model Designed to Create Service Value. Journal of Health Administration Education, 34(4), 525-55 